\title{
Change in Microbiological Conditions of Lawn Grass Root Zones as a Result of Fertilization with Sewage Sludge
}

\author{
Tomasz Pawel Kurowski ${ }^{1}$, Sebastian Wojciech Przemieniecki ${ }^{1 *}$, \\ Kazimierz Grabowski ${ }^{2}$, Marta Damszel ${ }^{1}$, Edyta Kwiatkowska ${ }^{1}$ \\ ${ }^{1}$ Department of Entomology, Phytopathology and Molecular Diagnostics, \\ University of Warmia and Mazury, Prawocheńskiego 17, 10-721 Olsztyn, Poland \\ ${ }^{2}$ Department of Grassland and Green Space Management, University of Warmia and Mazury, \\ Plac Łódzki 1, 10-727 Olsztyn, Poland
}

Received: 20 November 2015

Accepted: 12 April 2016

\begin{abstract}
Sewage sludge, thanks to its content of nutrients, can be used as a fertilizer for lawns. The aim of this study was to determine the relationship between the applied dose of sewage sludge and variety of lawn grasses and changes in the quality and quantity of microorganisms in the root zone of grass. The community of fungi isolated from the rhizoplane was significantly dominated by fungi belonging to the Fusarium genus, including F. oxysporum. The share of these fungi in the isolated community increased with the dose of sewage sludge. It was also found that the share of some saprotrophic fungi significantly increased after application of the sludge at a dose of $60 \mathrm{t} \bullet \mathrm{ha}^{-1}$ and decreased after its application at the highest dose of $150 \mathrm{t} \bullet \mathrm{ha}^{-1}$. The lowest number of fungi of the Fusarium genus was observed in the roots of perennial rye-grass $(30.3 \%$ of all isolates), while their highest number occurred in creeping red fescue (44.3\% of all isolates). Based on all the results, such as the level of dominance, the number of potential pathogens and bacteria and fungi saprotrophic observed that the dose of $60 t^{t} \mathrm{ha}^{-1}$ is the most favorable option, while the use of a dose of $150 \mathrm{t} \cdot \mathrm{ha}^{-1}$ may increase the share of pathogenic fungi in the community fungi, without causing beneficial changes in the number of microorganisms inhabiting rhizosferę terms lawns where no fertilizer was applied.
\end{abstract}

Keywords: sewage sludge, fertilization, lawn grass, fungal community, root zone microorganisms

\section{Introduction}

One of the main problems faced by municipal sewage treatment plants is excessive accumulation of waste produced during the sewage treatment process, i.e., sewage sludge. Sludge utilization using landfills is

*e-mail: microbiology@wp.pl an uneconomical solution. Alternative and more costeffective ways to use sewage sludge include: composting, direct use as a fertilizer, remediation of degraded areas, and as a source of energy [1-5]. Before application, the sludge should be properly prepared by a process of dehydration and stabilization [6-8].

Sewage sludge is rich in nutrients and elements responsible for the normal development of plants, and its 
proper application results in improved chemical parameters of the soil, an increase in $\mathrm{pH}$ value, and the content of humic substances, the formation of soil aggregates and improving their stability and sorption capacity. Due to its positive effects, this substrate can successfully compete with other types of organic fertilizers, as well as with mineral fertilizers [2, 9-10]. However, the possibility of using sewage sludge for fertilization is regulated by a decree by the Ministry of the Environment of 1 August 2002 (Dz. U. 2002/134/1140) on municipal sewage sludge.

A disadvantage of this type of fertilizer, formed on the basis of sewage sludge, is their variable chemical composition and the presence of toxic substances, including increased doses of heavy metals that may accumulate in the soil. The high content of organic matter and the introduction of pre-treatment and quality studies, as well as the adaptation of the sludge dose to the crop, can effectively minimize the impact of toxic substances, which is of particular importance in the cultivation of crops intended for consumption [10-12].

The rhizosphere is very important for the functioning of plants. As a zone of direct interaction between the soil and the roots, it is mainly responsible for the circulation of elements in nature and the formation of diverse specific groups of microorganisms [13]. In the rhizosphere, the microbial community can be formed by approximately $10^{4}$ species, and their count may reach $10^{8}-10^{9}$ per $g$ of wet weight of soil. The positive impact of plant-friendly microorganisms may result in the facilitation of nutrient uptake by roots, protection against colonization by pathogenic organisms, induction of defence mechanisms in the host plant, and easier distinction of harmful microorganisms from beneficial ones. An important aspect is the ability of the affected root zone to stimulate beneficial groups of microorganisms displacing plant pathogens, which has an impact on the health and yield of plants [14]. Important groups of microorganisms present in the rhizosphere that have a positive effect on plants comprise rhizobacteria, including the genera of Pseudomonas, Bacillus, Arthrobacter, Azospirillum, Azotobacter, Bradyrhizobium, and Rhizobium [14-16], as well as saprotrophic filamentous fungi [17] and yeast-like fungi [18].

Lawns have become an integral component of the urban environment due to their aspects related to aesthetics, recreation, scenery, and their positive impact on health owing to the detoxification of air and soil [19-20]. Proper fertilization improves the density of plants in the lawn, and their colour and ability to regenerate. The application of organic fertilizers in the spring or summer protects the sod and soil from drying and facilitates cultivation [19], as well as reduces the need for mineral fertilization [21-22]. Grasses are potential hosts for many fungal and bacterial pathogens that can disrupt the functioning of lawns and grasslands [23]. An area covered with grass and infested by pathogens becomes a focus of infection, threatening adjacent ecosystems. One of the most important factors that determine the usefulness of grass species and varieties for lawns is their resistance to pathogens. The influence of fertilization with sewage sludge on the healthy condition of lawns is not sufficiently described in literature; therefore, research in this field has been undertaken.

The aim of this study was to analyse the change in the count of selected types of rhizosphere microorganisms, and the structure of fungal communities present in the rhizoplane of three grass species under diversified fertilization with sewage sludge.

\section{Material and Methods}

Our study was conducted in the years 2003-06. The studied material consisted of three species of lawn grass: perennial rye-grass var. Trubadur (A), common meadowgrass var. Alicja (B), and creeping red fescue var. Areta (C). The scope of the study included a two-factor experiment in a randomized split-plot design on incomplete soil (aerosol) formed from loose sand on loamy dust, conducted in quadruplicate in the area of the Research and Education Centre of the Department of Horticulture at the University of Warmia and Mazury in Olsztyn (N:5345'36", E: $\left.20^{\circ} 27^{\prime} 08^{\prime \prime}\right)$. The experimental plots had dimensions of $1 \mathrm{~m} \cdot 1 \mathrm{~m}$. It was assumed that the use of the plots would be moderately intense; they would be irrigated during water deficiency periods and mowed 10-15 times during the growing season, corresponding to extensive use of the lawn grass. The characteristic properties of the soil are given Table 1.

Prior to sowing the grass, the soil was fertilized with a dose of 60 or 150 tons of sewage sludge per 1 ha. The sewage sludge was mixed with a $10 \mathrm{~cm}$ layer of soil. The higher dose of sewage sludge used in the study was the maximum dose that allows for mixing with the soil surface. The control group included plots that were not fertilized with sewage sludge. The characteristics of sewage sludge are given in Table 2.

Samples of roots were collected from the 3-6 July each year of the study. The microbiological analysis of the rhizosphere used the dilution method. From each experimental setting, $10 \mathrm{~g}$ of soil adhering to grass roots was placed in Erlenmeyer flasks containing $90 \mathrm{ml}$ of sterile water

Table 1. Physicochemical parameters of soil*.

\begin{tabular}{|c|c|c|c|c|c|c|c|c|}
\hline $\begin{array}{c}\text { Moisture } \\
(\% \text { vol. })\end{array}$ & $\begin{array}{c}\text { Organic matter } \\
\text { (\% of d.m.) }\end{array}$ & $\begin{array}{c}\mathrm{pH} \\
\text { (in KCl) }\end{array}$ & \multicolumn{2}{|c|}{$\begin{array}{c}\text { Total N } \\
\text { (\% of d.m.) }\end{array}$} & \multicolumn{4}{|c|}{ Total content of macronutrients (g.kg-1 d.m.) } \\
\hline & 2.80 & 6.20 & 0.10 & $\mathrm{P}$ & $\mathrm{K}$ & $\mathrm{Mg}$ & $\mathrm{Ca}$ & $\mathrm{Na}$ \\
\cline { 5 - 10 } & & & & 0.19 & 0.09 & 0.03 & 0.71 & 0.01 \\
\hline
\end{tabular}

*Vol. - volume; d.m. - dry mater 
Table 2. Primary parameters of sewage sludge used in this study.

\begin{tabular}{|c|c|c|c|c|c|c|c|c|c|}
\hline $\begin{array}{c}\text { Dry mass } \\
(\%)\end{array}$ & $\begin{array}{l}\text { Organic matter } \\
\text { (\% of d. m.) }\end{array}$ & $\begin{array}{c}\mathrm{pH} \\
\text { (in } \mathrm{KCl} \text { ) }\end{array}$ & \multicolumn{7}{|c|}{ Total content of macronutrients ( $\%$ of $\mathrm{d} . \mathrm{m})}$. \\
\hline \multirow{5}{*}{18.25} & \multirow{5}{*}{54.56} & \multirow{5}{*}{7.7} & $\mathrm{~N}$ & $\mathrm{P}$ & K & & & $\mathrm{Mg}$ & $\mathrm{Na}$ \\
\hline & & & 4.44 & 1.76 & 1.00 & & & 0.72 & 0.18 \\
\hline & & & \multicolumn{7}{|c|}{ Total concentration of heavy metals (mg.kg-1 d. m.)* } \\
\hline & & & $\mathrm{Zn}$ & $\mathrm{Cu}$ & $\mathrm{Pb}$ & $\mathrm{Ni}$ & $\mathrm{Cr}$ & $\mathrm{Cd}$ & $\mathrm{Hg}$ \\
\hline & & & $\begin{array}{c}2290 \\
(3,500)\end{array}$ & $\begin{array}{c}344 \\
(1,200)\end{array}$ & $\begin{array}{c}37.6 \\
(1,000)\end{array}$ & $\begin{array}{l}27.3 \\
(200)\end{array}$ & $\begin{array}{c}47.7 \\
(1,000)\end{array}$ & $\begin{array}{l}0.27 \\
(25)\end{array}$ & $\begin{array}{l}1.70 \\
(10)\end{array}$ \\
\hline
\end{tabular}

*Value in parentheses describes the maximum allowable concentration of heavy metals contained in sewage sludge used for land reclamation for non-agricultural purposes by the decree of the Ministry of the Environment of 1 August 2002 (Dz. U. 2002/134/1140) on municipal sewage sludge.

each. The samples were shaken using an Elpin plus 385S type bench laboratory shaker for $30 \mathrm{~min}$. Subsequently, by consecutive diluting $1 \mathrm{~cm}^{3}$ of the studied samples in test tubes containing $9 \mathrm{~cm}^{3}$ of sterile saline distilled water $(0.85 \% \mathrm{NaCl})$, a series of dilutions was obtained and $0.1 \mathrm{ml}$ of sample was transferred into the appropriate medium. In the quantitative microbiological analysis of the rhizosphere, filamentous and yeast-like fungi were isolated on a Martin's Rose Bengal Agar medium, while an agar medium without nitrogen and a King's B medium were used to determine the count of bacteria of Azotobacter and Pseudomonas genera, respectively. Due to technical problems, the total count of filamentous and yeast-like fungi isolated from the rhizosphere was not determined in 2004, which was the second year of the study. The results of the quantitative study of the microorganisms isolated from the rhizosphere were statistically analysed with Statistica 10 software (ANOVA) using Tukey's test.

Mycological analysis of the rhizoplane involved placing six fragments of thoroughly rinsed roots on a Petri dish with a potato dextrose agar (PDA) medium. Growing hyphae of the mycelium were transferred into agar slants and incubated at $25^{\circ} \mathrm{C}$ and 18 root samples from each experimental setting were applied. Microscopic analysis of the fungi was performed using generally available guidelines [24-30].

Microbiological analyses of the rhizosphere were performed in triplicate. The structure of the communities colonizing the rhizoplane was described using the species richness index, Simpson's dominance index, Simpson's diversity index, and Simpson's evenness index. The determination of taxonomic dominance hierarchy was performed using a five-point percentage scale applied in population-based studies of fungi [31-32].

\section{Results and Discussion}

During the four years of the experiment, a total number of 1,215 colonies, which represented 64 taxa, were isolated (Table 3). During the study we noted a decrease in the number of taxa of fungi. The population obtained during the four years was analysed as a whole. In terms of the specific aspect, the presence of eudominant $(>50 \%)$ in the three communities was not observed.

Among all the taxa present in the study, 18 groups occurred in each community. Analysis of 64 fungal species typically observed in the studies demonstrated only a dominance of Fusarium oxysporum (25.9\%). Sub-dominants included: Rhizopus stolonifer (12.3\%), Penicillium spp. $(7.7 \%)$ and Thanatephorus cucumeris (anamorph $=$ Rhizoctonia solani Kühn) (7.5\%). The dominance of $F$. oxysporum and sub-dominance of the three above-mentioned species was found for all the analysed grass species and sewage sludge doses. According to the applied dominance scale, both the analysis of the total population collected in the study and the analyses in terms of the grass species and fertilization doses did not show the presence of a eudominant taxon.

Analysis of the population of fungi present on the roots showed significant differences between varieties of grasses. In the community present in the rhizoplane of perennial rye-grass var. Trubadur consisting of 447 colonies belonging to 39 taxa, F. oxysporum constituted $21.7 \%$ of the population, while Rhizopus stolonifer, Penicillium spp., and Thanatephorus cucumeris constituted $12.1 \%$, $9.8 \%$, and $5.4 \%$ of the population, respectively. Other sub-dominant individuals were Phialophora spp. (11.2\%) and Mortierella alpina (6.5\%). Moreover, in this community, 10 rare taxa and 13 occasional taxa occurred. The community of fungi present in the rhizoplane of common meadow-grass var. Alicja consisted of a population of 374 colonies belonging to 38 species. F. oxysporum, Rhizopus stolonifer, Penicillium spp., and Thanatephorus cucumeris constituted $28.9 \%, 10.2 \%, 6.4 \%$, and $9.6 \%$ of the population, respectively. Another sub-dominant, Pyrenochaeta spp. (16.0\%), was present in this community. The number of rare and casual species equalled 11 and 21, respectively. Three-hundred and ninety-four colonies belonging to 42 species were obtained from the rhizosplane of creeping red fescue var. Areta. F. oxysporum constituted $27.9 \%$ of the population, while the sub-dominants comprised Rhizopus stolonifer $14.7 \%$, Penicillium spp. 6.3\%, Thanatephorus cucumeris $7.9 \%$, and Mucor hiemalis $5.1 \%$. Moreover, 16 rare taxa and 21 occasional taxa occurred in this community. 
Table 3. Structure of the fungal community isolated from the rhizoplane in terms of grass type and sewage sludge dose (the total results for the years 2003-06).

\begin{tabular}{|c|c|c|c|c|c|c|c|}
\hline \multirow{2}{*}{ Strain of fungi } & \multicolumn{3}{|c|}{ Species of grass* } & \multicolumn{3}{|c|}{ Dose of sludge $\left[\mathrm{t}^{*} \mathrm{ha}^{-1}\right]$} & \multirow{2}{*}{ Sum } \\
\hline & $\mathbf{A}$ & B & $\mathrm{C}$ & $\mathbf{0}$ & 60 & 150 & \\
\hline Acremonium charticola (Lindau) W. Gams & 0 & 2 & 0 & 2 & 0 & 0 & 2 \\
\hline Acremonium furcatum (F. et V. Moreau) ex W. Gams & 1 & 0 & 0 & 0 & 0 & 1 & 1 \\
\hline Acremonium persicinum (Nicot) W. Gams & 4 & 0 & 0 & 4 & 0 & 0 & 4 \\
\hline Acremonium rutilum $\mathrm{W}$. Gams & 0 & 0 & 1 & 0 & 1 & 0 & 1 \\
\hline Alternaria alternata (Fries) Keissler & 1 & 0 & 2 & 1 & 1 & 1 & 3 \\
\hline Arthrinium phaeospermum (Corda) M.B. Ellis & 0 & 1 & 0 & 1 & 0 & 0 & 1 \\
\hline Arthrinium spp. & 0 & 0 & 5 & 5 & 0 & 0 & 5 \\
\hline Aspergillus fumigatus Fresenius & 1 & 0 & 0 & 0 & 0 & 1 & 1 \\
\hline Aspergillus niger vanTiegh & 0 & 1 & 1 & 1 & 0 & 1 & 2 \\
\hline Aureobasidium pullulans (de Bary) Arnaud. & 8 & 1 & 9 & 12 & 4 & 2 & 18 \\
\hline Cephalotrichum purpureofuscum (Schwein.) S. Hughes & 10 & 1 & 0 & 10 & 1 & 0 & 11 \\
\hline Chaetomium spp. & 4 & 0 & 1 & 0 & 0 & 5 & 5 \\
\hline Cladosporium cladosporioides (Fres.) de Vries & 4 & 2 & 5 & 4 & 3 & 4 & 11 \\
\hline Cladosporium herbarum Link ex Fr. & 0 & 3 & 0 & 3 & 0 & 0 & 3 \\
\hline $\begin{array}{l}\text { Clonostachys rosea (Link) Schroers, Samuels, Seifert et W. } \\
\text { Gams }\end{array}$ & 0 & 1 & 2 & 0 & 2 & 1 & 3 \\
\hline Epicoccum nigrum Link & 1 & 2 & 0 & 0 & 3 & 0 & 3 \\
\hline Fusarium chlamydosporum Wollenw. et Reinking & 3 & 0 & 1 & 1 & 1 & 2 & 4 \\
\hline Fusarium culmorum W.G. Smith & 0 & 0 & 6 & 0 & 4 & 2 & 6 \\
\hline Fusarium incarnatum (Desm.) Sacc. & 1 & 0 & 0 & 0 & 1 & 0 & 1 \\
\hline Fusarium oxysporum Schltdl. & 97 & 108 & 110 & 93 & 101 & 121 & 315 \\
\hline Gibberella acuminata Wollenw & 0 & 2 & 0 & 0 & 2 & 0 & 2 \\
\hline Gibberella avenacea R.J. Cook & 2 & 7 & 9 & 3 & 4 & 11 & 18 \\
\hline Gibberella intricans Wollenw. & 11 & 4 & 9 & 8 & 9 & 7 & 24 \\
\hline Gibberella zeae (Schwein.) Petch, & 0 & 0 & 1 & 0 & 1 & 0 & 1 \\
\hline $\begin{array}{l}\text { Haematonectria haematococca (Berk. et Broome) Samuels } \\
\text { et Rossman }\end{array}$ & 1 & 1 & 4 & 2 & 3 & 1 & 6 \\
\hline Hormiactis candida V. Höhnel & 3 & 0 & 0 & 3 & 0 & 0 & 3 \\
\hline Humicola fuscoatra Traaen & 1 & 0 & 0 & 0 & 1 & 0 & 1 \\
\hline Humicola grisea Taaen & 0 & 8 & 1 & 0 & 8 & 1 & 9 \\
\hline Microdochium bolleyi (Sprague) de Hoog et Herm.-Nijh & 10 & 2 & 2 & 3 & 9 & 2 & 14 \\
\hline Monodictys castaneae (Wallr.) Hugnes & 0 & 0 & 1 & 1 & 0 & 0 & 1 \\
\hline Monographella nivalis (Schaffnit) E. Müll. & 0 & 6 & 9 & 5 & 0 & 10 & 15 \\
\hline Mortierella alpina Peyronel & 29 & 9 & 18 & 21 & 29 & 6 & 56 \\
\hline Mortierella capitata Marchal & 3 & 0 & 0 & 3 & 0 & 0 & 3 \\
\hline Mortierella globulifera O. Rostr. & 1 & 0 & 0 & 0 & 1 & 0 & 1 \\
\hline Mortierella jenkini (Naumov) Smith & 0 & 1 & 4 & 0 & 5 & 0 & 5 \\
\hline Mortierella simplex van Tieghem et Le Monnier & 0 & 1 & 1 & 1 & 0 & 1 & 2 \\
\hline Mortierella verrucosa Linn. & 0 & 0 & 1 & 0 & 0 & 1 & 1 \\
\hline
\end{tabular}




\begin{tabular}{|c|c|c|c|c|c|c|c|}
\hline Mortierella verticillata Linn. & 1 & 0 & 0 & 1 & 0 & 0 & 1 \\
\hline Mortierella zonata Linnem. ex W. Gams & 6 & 7 & 5 & 5 & 9 & 4 & 18 \\
\hline Mucor circinelloides van Tieghem & 5 & 0 & 2 & 0 & 4 & 3 & 7 \\
\hline Mucor hiemalis Wehmer & 3 & 3 & 20 & 7 & 5 & 14 & 26 \\
\hline Myrothecium verrucaria (Alb. et Schwein.) Ditmar & 3 & 2 & 6 & 2 & 3 & 6 & 11 \\
\hline Penicillium spp. & 44 & 24 & 25 & 34 & 35 & 24 & 93 \\
\hline Phialophora spp. & 50 & 0 & 0 & 9 & 0 & 41 & 50 \\
\hline Phoma eupyrena Sacc. & 0 & 0 & 2 & 0 & 0 & 2 & 2 \\
\hline Phoma herbarum Westend & 17 & 7 & 12 & 19 & 15 & 2 & 36 \\
\hline Phoma humicola Gilman et Abbott & 0 & 0 & 2 & 2 & 0 & 0 & 2 \\
\hline Pseudonectria buxi (DC.) Seifert, Gräfenhan et Schroers & 4 & 7 & 0 & 0 & 10 & 1 & 11 \\
\hline Pyrenochaeta spp. & 0 & 60 & 0 & 60 & 0 & 0 & 60 \\
\hline Rhizopus stolonifer (Ehrenb.) Vuill. & 54 & 38 & 58 & 66 & 37 & 47 & 150 \\
\hline Sarocladium strictum (W. Gams) Summerb. & 2 & 1 & 4 & 4 & 1 & 2 & 7 \\
\hline Scopulariopsis brumptii Salvanet-Duval & 0 & 3 & 2 & 2 & 1 & 2 & 5 \\
\hline Scopulariopsis chartarum (G. Smith) Morton et G. Smith & 2 & 1 & 0 & 1 & 0 & 2 & 3 \\
\hline $\begin{array}{l}\text { Sphaerostilbella aureonitens (Tul. et C. Tul.) Seifert, Samu- } \\
\text { els \& W. Gams }\end{array}$ & 0 & 0 & 1 & 1 & 0 & 0 & 1 \\
\hline Thanatephorus cucumeris (A.B. Frank) Donk & 24 & 36 & 31 & 25 & 21 & 45 & 91 \\
\hline Trichoderma aureoviride Rifai & 8 & 4 & 3 & 8 & 7 & 0 & 15 \\
\hline Trichoderma deliquescens (Sopp) Jaklitsch & 0 & 2 & 0 & 0 & 2 & 0 & 2 \\
\hline Trichoderma hamatum (Bon.) Bain. & 13 & 0 & 10 & 8 & 2 & 13 & 23 \\
\hline Trichoderma harzianum Rifai & 0 & 7 & 1 & 2 & 6 & 0 & 8 \\
\hline Trichoderma koningii Oud. & 0 & 1 & 0 & 0 & 1 & 0 & 1 \\
\hline Trichoderma viride Persoon ex S.F. Gray & 1 & 2 & 1 & 1 & 2 & 1 & 4 \\
\hline Trichothecium roseum (Persoon ex Fries) Link & 1 & 0 & 0 & 0 & 0 & 1 & 1 \\
\hline Umbelopsis isabellina (Oudem.) W. Gams & 0 & 6 & 4 & 5 & 4 & 1 & 10 \\
\hline Wardomyces ovalis W. Gams & 13 & 0 & 2 & 0 & 2 & 13 & 15 \\
\hline Sum & 447 & 374 & 394 & 449 & 361 & 405 & 1,215 \\
\hline
\end{tabular}

* A - perennial rye-grass, B - common meadow-grass, $\mathrm{C}$ - creeping red fescue

\begin{tabular}{|c|c|}
\hline \multicolumn{2}{|c|}{ Scale of domination } \\
\hline $20-50 \%$ & dominant \\
\hline $5-20 \%$ & subdominant \\
\hline $1-5 \%$ & rare individuals \\
\hline$<1 \%$ & casual individuals \\
\hline $0 \%$ & not observed \\
\hline
\end{tabular}

The number of species present in the respective studies was relatively similar. However, only 18 species were the same in each of the communities. Species richness (S) of fungal communities analysed in terms of grass variety reached similar values. The highest richness $(S=42)$ occurred in the rhizoplane of creeping red fescue var. Areta.
Simpson's dominance index $(\lambda)$ revealed that none of the three communities occurring in the grass rhizoplane was distinctly dominated by any of the fungal species (Table 4), which indicates the lack of a eudominant species ( $>50 \%$ of the population). The only form exhibiting dominance was $F$. oxysporum present in each population, 
Table 4. Structural indicators for the communities of fungal species.

\begin{tabular}{|c|c|c|c|c|c|c|c|}
\hline \multirow{2}{*}{ Indicator } & \multirow{2}{*}{ Formula } & \multicolumn{3}{|c|}{ Species of grass* } & \multicolumn{3}{|c|}{ Dose of sludge $\left(\mathrm{t} \bullet \mathrm{ha}^{-1}\right)$} \\
\cline { 3 - 7 } & & $\mathrm{A}$ & $\mathrm{B}$ & $\mathrm{C}$ & 0 & 60 & 150 \\
\hline Species richness $(\mathrm{S})$ & Number of taxa & 39 & 38 & 42 & 42 & 41 & 39 \\
\hline Simpson's dominance index $(\lambda)$ & $\lambda=\sum p_{i}^{2}$ & 0.10 & 0.14 & 0.12 & 0.10 & 0.12 & 0.13 \\
\hline Simpson's diversity index $(\mathrm{C})$ & $\mathrm{C}=1-\sum p_{i}^{2}$ & 0.90 & 0.86 & 0.88 & 0.90 & 0.88 & 0.87 \\
\hline Simpson's diversity index (D) & $\mathrm{D}=1 /\left(\sum p_{i}^{2}\right)$ & 10.27 & 7.31 & 8.34 & 10.09 & 8.69 & 7.41 \\
\hline Simpson's evenness index (E) & $\mathrm{E}=\mathrm{D} / \mathrm{S}$ & 0.22 & 0.16 & 0.20 & 0.21 & 0.18 & 0.18 \\
\hline
\end{tabular}

$p_{i}^{2}$ - probability of sequentially selecting two individuals of the same species

$* \mathrm{~A}$ - perennial rye-grass, $\mathrm{B}$ - common meadow-grass, $\mathrm{C}$ - creeping red fescue

and in addition, each of the communities comprised three sub-dominants (Table 3). Diversity index (C) showed that each of the fungal populations was characterized by a high level of species diversity $(\mathrm{C}=0.90-0.86)$.

As for the aspect of sewage sludge fertilization, the distribution of the individual taxa share was similar for each dose. The community of fungi isolated from the rhizoplane of grasses not fertilized with sewage sludge, comprising 449 species, was dominated by F. oxysporum (20.7\%). The sub-dominants included four species: Rhizopus stolonifer (14.7\%), Pyrenochaeta spp. (13.4\%), Penicillium spp. (7.6\%), and Thanatephorus cucumeris (5.6\%). Moreover, in this community, 13 rare taxa and 24 occasional taxa were recorded. In the community isolated

Table 5. Structure of communities of the most numerous significant group of fungi isolated from the rhizoplane in terms of grass type and sewage sludge dose (total results for 2003-06).

\begin{tabular}{|c|c|c|c|c|c|c|c|}
\hline \multirow{3}{*}{ Strain of fungi } & \multirow{2}{*}{\multicolumn{3}{|c|}{ Strain of grass* }} & \multirow{2}{*}{\multicolumn{3}{|c|}{$\frac{\text { Dose of sludge }}{\left(t \cdot h a^{-1}\right)}$}} & \multirow{3}{*}{ Sum } \\
\hline & & & & & & & \\
\hline & $\mathrm{A}$ & B & $\mathrm{C}$ & 0 & 60 & 150 & \\
\hline Acremonium spp, + Sarocladium strictum & 7 & 3 & 5 & 10 & 2 & 3 & 15 \\
\hline Aureobasidium spp. + Microdochium bolleyi & 18 & 3 & 11 & 15 & 13 & 4 & 32 \\
\hline $\begin{array}{c}\text { Fusarium spp. + Gibberella spp. + Haematonectria } \\
\text { haematococca }+ \text { Monogaphella nivalis }\end{array}$ & 115 & 128 & 149 & 112 & 126 & 154 & 385 \\
\hline Gliocladium spp. & 3 & 5 & 9 & 3 & 7 & 7 & 17 \\
\hline Mortierella spp. + Umbelopsis isabellina & 40 & 24 & 33 & 36 & 48 & 13 & 97 \\
\hline Penicillium spp. & 44 & 24 & 25 & 34 & 35 & 24 & 93 \\
\hline Phialophora spp. & 50 & 0 & 0 & 9 & 0 & 41 & 50 \\
\hline Pyrenochaeta spp. & 0 & 60 & 0 & 60 & 0 & 0 & 60 \\
\hline Thanatephorus spp. & 24 & 36 & 31 & 25 & 21 & 45 & 91 \\
\hline Rhizopus spp. & 53 & 38 & 56 & 63 & 37 & 47 & 147 \\
\hline Scopulariopsis spp. & 2 & 4 & 2 & 3 & 1 & 4 & 8 \\
\hline Trichoderma spp. & 23 & 14 & 15 & 19 & 18 & 15 & 52 \\
\hline Sum & 379 & 339 & 336 & 389 & 308 & 357 & 1,047 \\
\hline
\end{tabular}

* A - perennial rye-grass, $\mathrm{B}$ - common meadow-grass, $\mathrm{C}$ - creeping red fescue

\begin{tabular}{|c|c|}
\hline \multicolumn{2}{|c|}{ Scale of domination } \\
\hline $20-50 \%$ & dominant \\
\hline $5-20 \%$ & subdominant \\
\hline $1-5 \%$ & rare individuals \\
\hline$<1 \%$ & casual individuals \\
\hline $0 \%$ & not observed \\
\hline
\end{tabular}


from the rhizoplane of grasses fertilized with sewage sludge at a dose of $60 \mathrm{t} \bullet \mathrm{ha}^{-1}$, including 361 colonies, no presence of a eudominant taxon was found. The dominant form was $F$. oxysporum (28.9\%). The group of subdominants consisted of the following species: Rhizopus stolonifer (10.2\%), Penicillium spp. (9.7\%), Mortierella alpina (8.0\%), and Thanatephorus cucumeris (5.8\%). The remaining colonies formed 15 rare taxa and 21 occasional taxa. In the community of 405 colonies, isolated from the grasses fertilized with sewage sludge at a dose of 150 t ha $^{-1}$, the dominant form was F. oxysporum (29.9\%). The sub-dominant group included: Rhizopus stolonifer (11.6\%), T. cucumeris (11.1\%), Phialophora spp. (10.1\%), and Penicillium spp. (5.9\%). The community comprised nine rare taxa and 25 occasional taxa.

Analysis of ecological indicators of fungal communities occurring in the rhizoplane of plants treated with different doses of sewage sludge revealed similar relationships, as in the case of the analysis of fungal communities occurring in the rhizoplane of different grass varieties. Species richness (S) equalled 42 for the community present in unfertilized plants, while for the $60 \mathrm{t} \bullet \mathrm{ha}^{-1}$ and 150 t $^{\circ} \mathrm{ha}^{-1}$ doses it equalled 41 and 39, respectively. Simpson's dominance index $(\lambda)$ did not indicate the dominance of any taxon. However, the diversity index (C) demonstrated that each fungal population was characterized by a high level of species diversity (0.84-0.76), which was also confirmed by the evenness index (D). Similar to the case of the analysis of the fungal community according to species, Simpson's evenness index (E) had low values due to the presence of numerous individual casual taxa.

Due to the high proportion of rare and casual taxa in the isolated community, an analysis of the dominance of the major fungal species was performed (Table 5). The highest count and share in the analysed community was reached by fungi of the Fusarium genus (average share $36.8 \%$ ). In the case of varieties, their count and share were significantly higher in creeping red fescue (share 44.4\%), while in the case of other sewage sludge fertilization variants, the count increased with the dose and, at a dose of 150 t $\bullet \mathrm{h}^{-1}$, was $37 \%$ higher in comparison to the population originating from unfertilized plants.

The distribution of species richness for the analysis of the specific factor and fertilization dose was similar. In pe- rennial rye-grass, the species richness was low, while in common meadow-grass and creeping red fescue, the share of the dominant was more pronounced $(\lambda>20)$. This result was confirmed by both evenness indices, which were significantly higher for perennial rye-grass, and low evenness indices, which reached only $\mathrm{E}=10$ for common meadowgrass and red fescue. In the case of fertilizer doses, the dominance index increased with the dose, but the difference between 60 and $150 \mathrm{t} \bullet \mathrm{ha}^{-1}$ variants was small $(\lambda=1)$. The diversity and evenness indices were similar for 60 and 150 t $h^{-1}$ doses, and significantly lower in comparison to the unfertilized variant (Table 6).

During the study of fungal communities, it was observed that the number of pathogenic fungi isolated from the rhizosphere of grasses increased with doses of sewage sludge. The ratio of phytopathogens to saprophytes was similar in both doses of fertilization and was approximately 0.42 , while in unfertilized grass it was 0.36 . Depending on the species of grasses, most pathogenic fungi were isolated from the rizosphere of creeping red fescue, and the ratio of of phytopathogens to saprophytes was 0.44 and increased by 0.14 and 0.06 in comparison with the population of fungi isolated from rye-grass and common meadow-grass, respectively (Table 5).

In the analysed population, we found the presence of saprotrophically developing fungi such as Aureobasidium, Mortierella, Mucor, Penicillium, Rhizopus, and Trichoderma. Due to antagonistic action against plant pathogens, a high proportion of these species in the community is a limiting factor for the infection of plants with phytopathogens [33].

Previous studies suggest that in the autumn and winter period, the fungal species Limonomyces roseipellis, Laetisaria fuciformis, and Monographella nivalis occur with high intensity on grasses with a high proportion of perennial rye-grass. By contrast, the infection of red fescue can be caused, in addition to typical autumn and winter period pathogens, by Rhizoctonia, Fusarium, Bipolaris, and Drechslera. Common meadow-grass is susceptible to infection by Puccinia spp., Drechslera poae, and Blumeria graminis fungi [34-36]. However, during the studies of sports ground turf, it was observed that Fusarium and Rhizoctonia fungal species also adversely affect the healthy condition of the grass in the summer.

Table 6. Structural indicators for the communities of frequently occurring significant groups of fungi.

\begin{tabular}{|c|c|c|c|c|c|c|c|}
\hline \multirow{2}{*}{ Indicator } & \multirow{2}{*}{ Formula } & \multicolumn{3}{|c|}{ Species of grass* } & \multicolumn{3}{|c|}{ Dose of sludge $\left(t \cdot h a^{-1}\right)$} \\
\hline & & $\mathbf{A}$ & B & $\mathbf{C}$ & $\mathbf{0}$ & 60 & 150 \\
\hline Species richness $(\mathrm{S})$ & Number of taxa & 11 & 11 & 10 & 12 & 10 & 11 \\
\hline Simpson's dominance index $(\lambda)$ & $\lambda=\sum p_{i}^{2}$ & 0.16 & 0.21 & 0.25 & 0.16 & 0.23 & 0.24 \\
\hline Simpson's diversity index - fraction (C) & $\mathrm{C}=1-\sum p_{i}^{2}$ & 0.84 & 0.79 & 0.75 & 0.84 & 0.77 & 0.76 \\
\hline Simpson's diversity index (D) & $\mathrm{D}=1 /\left(\sum p_{i}^{2}\right)$ & 6.24 & 4.80 & 4.00 & 6.41 & 4.43 & 4.18 \\
\hline Simpson's evenness index (E) & $\mathrm{E}=\mathrm{D} / \mathrm{S}$ & 0.13 & 0.10 & 0.10 & 0.14 & 0.09 & 0.10 \\
\hline
\end{tabular}

$p_{i}^{2}$ - probability of sequentially selecting two individuals of the same species

${ }^{*} \mathrm{~A}-$ perennial rye-grass, $\mathrm{B}$ - common meadow-grass, $\mathrm{C}$ - creeping red fescue 
Table 7. Count of bacteria of the Azotobacter genus isolated from the rhizosphere of grasses $\left(\log 10 \cdot \mathrm{g}^{-1} \mathrm{soil}\right)$.

\begin{tabular}{|c|c|c|c|c|c|c|c|c|c|c|c|c|c|}
\hline \multirow{2}{*}{\multicolumn{2}{|c|}{$\begin{array}{c}\text { Strain of grass } \\
\begin{array}{c}\text { Dose of sewage } \\
\text { sludge }\left(\mathbf{t} \cdot \mathbf{h a}^{-1}\right)\end{array}\end{array}$}} & \multicolumn{3}{|c|}{ Perennial rye-grass } & \multicolumn{3}{|c|}{ Common meadow-grass } & \multicolumn{3}{|c|}{ Creeping red fescue } & \multicolumn{3}{|c|}{$\begin{array}{c}\text { Mean dose of sewage } \\
\text { sludge }\end{array}$} \\
\hline & & $\mathbf{0}$ & 60 & 150 & $\mathbf{0}$ & 60 & 150 & $\mathbf{0}$ & 60 & 150 & 0 & 60 & 150 \\
\hline \multirow{4}{*}{ 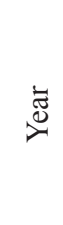 } & I & $5.53 \mathrm{c}$ & $5.64 b-c$ & $5.88 \mathrm{ab}$ & $5.56 \mathrm{c}$ & $5.67 \mathrm{bc}$ & $5.59 \mathrm{c}$ & $5.64 b-c$ & $5.73 \mathrm{a}-\mathrm{c}$ & $6.00 \mathrm{a}$ & 5.58 & 5.68 & 5.82 \\
\hline & II & $5.58 \mathrm{c}$ & $5.55 \mathrm{c}$ & $5.52 \mathrm{c}$ & $5.57 \mathrm{c}$ & $5.55 \mathrm{c}$ & $5.49 \mathrm{c}$ & $5.58 \mathrm{c}$ & $5.54 \mathrm{c}$ & $5.61 b-c$ & 5.58 & 5.55 & 5.54 \\
\hline & III & $4.11 \mathrm{e}-\mathrm{h}$ & $3.72 \mathrm{j}$ & $4.33 \mathrm{de}$ & $4.15 \mathrm{e}-\mathrm{g}$ & $4.17 \mathrm{e}-\mathrm{g}$ & $4.13 \mathrm{e}-\mathrm{g}$ & $4.13 \mathrm{e}-\mathrm{g}$ & $3.93 \mathrm{~g}-\mathrm{j}$ & $4.02 \mathrm{f}-\mathrm{i}$ & 4.13 & 3.94 & 4.16 \\
\hline & IV & $3.76 \mathrm{ij}$ & $4.28 \mathrm{ef}$ & $4.55 \mathrm{~d}$ & $4.18 \mathrm{e}-\mathrm{g}$ & $4.15 \mathrm{e}-\mathrm{g}$ & $3.93 g-j$ & $3.85 \mathrm{~h}-\mathrm{j}$ & $5.74 a-c$ & $4.21 \mathrm{ef}$ & 3.93 & 4.72 & 4.23 \\
\hline \multirow{2}{*}{\multicolumn{2}{|c|}{ Mean }} & 4.75 & 4.80 & 5.07 & 4.87 & 4.89 & 4.79 & 4.80 & 5.24 & 4.96 & $4.80 \mathrm{Y}$ & $4.97 X$ & $4.94 X$ \\
\hline & & \multicolumn{3}{|c|}{ 4.87B } & \multicolumn{3}{|c|}{$4.85 B$} & \multicolumn{3}{|c|}{$5.00 \mathrm{~A}$} & & & \\
\hline
\end{tabular}

Results with the same letter (year • dose: small letters; mean for types of grasses: A or B; mean for doses: X or Y) are not significantly different; LSD $(\mathrm{p}<0.05)$

The authors emphasized that perennial rye-grass (Lolium perenne L.) and common meadow-grass (Poa pratensis L.) are more resistant to some factors determining the quality of grasses, such as low mowing and intensive trampling [37].

In other studies, based on the example of perennial rye-grass, it was shown that one of the factors affecting the healthy condition of grass was the course of weather conditions after winter, resulting from lack of snow cover and long-lasting temperatures of approximately $0^{\circ} \mathrm{C}$. Mould was observed in the period after winter snow, and its intensity was higher every year of observation. Powdery mildew dominated among the pathogens affecting grass health during the blooming period, while rusts dominated in the autumn. But the presence of pathogens was not the only cause of grass dying out [38]. In contrast, the degree of grass decay with the years passing is affected by grass variety, but grass susceptibility to infections is higher in humid weather and at high temperatures, which favours the development of fungi of the Fusarium, Rhizoctonia, and Bipolaris genera [36]. The intensification of occurrence of snow mould was also dependent on the type of mineral fertilizers, which was observed in the studies of Jankowski et al. [39]. However, apart from long-lasting snow cover, another important factor that intensifies grass infestation with pathogens is an unfavourable balance of fertilization. An increase in the occurrence of snow mould (M. nivalis) and rhizoctoniosis (Rhizoctonia spp.) can be caused by over-fertilization with nitrogen [36].

Bacteria of the Azotobacter genus occurred most often in red fescue, while in terms of sludge fertilization a comparable count of Azotobacter spp. was isolated from plants fertilized with doses of 60 and $150 \mathrm{t}^{\bullet} \mathrm{ha}^{-1}$, which was significantly higher in comparison to unfertilized plants. Among grass species, the least variable bacterial count occurred in common meadow-grass. Analysis of individual years did not show any significant differences for any of the studied years. In the first and last year of the study, an increase in bacterial count with the sludge dose in perennial rye-grass occurred, while in 2005 a significantly lower result was obtained for the dose of $60 \mathrm{t}^{\circ} \mathrm{ha}^{-1}$. Analysis of the second year did not demonstrate any significant changes in the Azotobacter spp. count for any of the doses. A similar dependency was observed in red fescue.

Table 8. Count of bacteria of the Pseudomonas genus isolated from the rhizosphere of the grasses $\left(\log 10 \cdot \mathrm{g}^{-1} \mathrm{soil}\right)$.

\begin{tabular}{|c|c|c|c|c|c|c|c|c|c|c|c|c|c|}
\hline \multirow{2}{*}{\multicolumn{2}{|c|}{$\begin{array}{c}\text { Strain of grass } \\
\begin{array}{c}\text { Dose of sewage } \\
\text { sludge }\left(\mathbf{t} \cdot \mathbf{h a}^{-1}\right)\end{array}\end{array}$}} & \multicolumn{3}{|c|}{ Perennial rye-grass } & \multicolumn{3}{|c|}{ Common meadow-grass } & \multicolumn{3}{|c|}{ Creeping red fescue } & \multicolumn{3}{|c|}{$\begin{array}{l}\text { Mean dose of sewage } \\
\text { sludge }\end{array}$} \\
\hline & & 0 & 60 & 150 & 0 & 60 & 150 & 0 & 60 & 150 & 0 & 60 & 150 \\
\hline \multirow{4}{*}{ 気 } & I & $8.45 \mathrm{bc}$ & $8.63 \mathrm{a}-\mathrm{c}$ & $8.81 \mathrm{a}$ & $8.39 \mathrm{c}$ & $8.58 \mathrm{a}-\mathrm{c}$ & $8.63 \mathrm{a}-\mathrm{c}$ & $8.43 \mathrm{c}$ & $8.52 \mathrm{a}-\mathrm{c}$ & $8.73 \mathrm{ab}$ & 8.42 & 8.58 & 8.72 \\
\hline & II & $4.51 \mathrm{n}$ & $4.53 \mathrm{mn}$ & $5.01 \mathrm{jk}$ & $5.21 \mathrm{~h}-\mathrm{j}$ & $4.84 \mathrm{kl}$ & $4.84 \mathrm{kl}$ & $4.83 \mathrm{k}-\mathrm{m}$ & $5.21 \mathrm{~h}-\mathrm{j}$ & $5.22 \mathrm{~h}-\mathrm{j}$ & 4.85 & 4.86 & 5.02 \\
\hline & III & $4.52 \mathrm{n}$ & $4.01 \mathrm{o}$ & $4.48 n$ & $3.53 \mathrm{p}$ & $4.561-n$ & $4.37 \mathrm{n}$ & $4.53 \mathrm{mn}$ & $5.06 \mathrm{i}-\mathrm{k}$ & $4.591-n$ & 4.19 & 4.54 & 4.48 \\
\hline & IV & $5.18 \mathrm{~h}-\mathrm{j}$ & $5.63 \mathrm{ef}$ & $6.28 \mathrm{~d}$ & $5.43 \mathrm{f}-\mathrm{h}$ & $5.79 \mathrm{e}$ & $5.66 \mathrm{ef}$ & $5.60 \mathrm{e}-\mathrm{g}$ & $5.32 \mathrm{~g}-\mathrm{i}$ & $6.18 \mathrm{~d}$ & 5.40 & 5.58 & 6.04 \\
\hline \multirow{2}{*}{\multicolumn{2}{|c|}{ Mean }} & 5.67 & 5.70 & 6.15 & 5.64 & 5.94 & 5.88 & 5.85 & 6.03 & 6.18 & $5.72 Z$ & $5.89 \mathrm{Y}$ & $6.07 X$ \\
\hline & & \multicolumn{3}{|c|}{$5.84 B$} & \multicolumn{3}{|c|}{$5.82 B$} & \multicolumn{3}{|c|}{$6.02 \mathrm{~A}$} & & & \\
\hline
\end{tabular}

Results with the same letter (year • dose: small letters; mean for types of grasses: A or B; mean for doses: X, Y or Z) are not significantly different; LSD $(\mathrm{p}<0.05)$ 
Table 9. Count of filamentous fungi isolated from the rhizosphere of the grasses $\left(\log 10 \cdot \mathrm{g}^{-1} \mathrm{soil}\right)$.

\begin{tabular}{|c|c|c|c|c|c|c|c|c|c|c|c|c|c|}
\hline \multirow{2}{*}{\multicolumn{2}{|c|}{\begin{tabular}{|c} 
Strain of grass \\
$\begin{array}{c}\text { Dose of sewage } \\
\text { sludge }\left(\mathbf{t} \cdot \mathbf{h a}^{-1}\right)\end{array}$
\end{tabular}}} & \multicolumn{3}{|c|}{ Perennial rye-grass } & \multicolumn{3}{|c|}{ Common meadow-grass } & \multicolumn{3}{|c|}{ Creeping red fescue } & \multicolumn{3}{|c|}{$\begin{array}{c}\text { Mean dose of sewage } \\
\text { sludge }\end{array}$} \\
\hline & & $\mathbf{0}$ & 60 & 150 & $\mathbf{0}$ & 60 & 150 & $\mathbf{0}$ & 60 & 150 & 0 & 60 & 150 \\
\hline \multirow{3}{*}{ 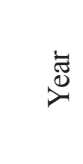 } & I & $4.49 \mathrm{~b}$ & $4.53 \mathrm{ab}$ & $4.75 \mathrm{a}$ & $4.51 \mathrm{ab}$ & $4.11 \mathrm{c}$ & $4.62 \mathrm{ab}$ & $4.52 \mathrm{ab}$ & $4.40 \mathrm{~b}$ & $3.03 \mathrm{ij}$ & 4.51 & 4.38 & 4.52 \\
\hline & III & $2.52 \mathrm{k}$ & $2.52 \mathrm{k}$ & $3.12 \mathrm{hi}$ & $2.52 \mathrm{k}$ & $2.83 \mathrm{j}$ & $3.37 \mathrm{e}-\mathrm{g}$ & $2.83 \mathrm{j}$ & $3.03 \mathrm{ij}$ & $3.22 \mathrm{~g}-\mathrm{i}$ & 2.65 & 2.82 & 3.25 \\
\hline & IV & $2.48 \mathrm{k}$ & $3.85 \mathrm{~d}$ & $3.60 \mathrm{de}$ & $2.48 \mathrm{k}$ & $3.31 \mathrm{f}-\mathrm{h}$ & $3.78 \mathrm{~d}$ & $2.48 \mathrm{k}$ & $3.30 \mathrm{f}-\mathrm{h}$ & $3.48 \mathrm{ef}$ & 2.48 & 3.56 & 3.64 \\
\hline \multirow{2}{*}{\multicolumn{2}{|c|}{ Mean }} & 3.16 & 3.63 & 3.82 & 3.17 & 3.42 & 3.92 & 3.28 & 3.58 & 3.24 & $3.21 \mathrm{Z}$ & $3.59 \mathrm{Y}$ & $3.80 \mathrm{X}$ \\
\hline & & \multicolumn{3}{|c|}{$3.54 \mathrm{~A}$} & \multicolumn{3}{|c|}{$3.50 \mathrm{~A}$} & \multicolumn{3}{|c|}{ 3.37B } & & & \\
\hline
\end{tabular}

Results with the same letter (year • dose: small letters; mean for the types of grasses: A or B; mean for doses: X, Y or Z) are not significantly different; LSD $(\mathrm{p}<0.05)$

However, in 2006 the highest count of microorganisms occurred at a dose of $60 \mathrm{t} \bullet \mathrm{ha}^{-1}$, reaching the same result as in the first year of the study, and the increase in the bacterial count was two orders of magnitude higher than in 2005 (Table 7).

Changes in the bacterial count of the Pseudomonas genus showed a partially similar tendency, as in the case of Azotobacter. An increase in the bacterial count was reported in the last year of the study. Pseudomonas spp. were the most frequent in red fescue, and the increasing sludge dose had a stimulating effect on their development. In the case of perennial rye-grass, the bacteria count significantly increased in each of the studied years (with the exception of 2005, in which a significant result among the doses of 60 and $150 \mathrm{t}^{\circ} \mathrm{ha}^{-1}$ was found only for $\left.60 \mathrm{t} \cdot \mathrm{ha}^{-1}\right)$. The count of bacteria isolated from common meadow-grass fertilized with different sludge doses showed various tendencies, depending on the year of studies. Nevertheless, based on the analysis of the average value from all years for the 60 and 150 t $^{\circ \mathrm{ha}^{-1}}$ doses, an increased bacterial count was observed, especially for the $60 \mathrm{t}^{\bullet} \mathrm{ha}^{-1}$ dose. Red fescue showed a tendency comparable to perennial rye-grass. In each year (except for 2005) an increase in the Pseudomonas spp. count in the plants fertilized with sludge was demonstrated, which occurred most visibly in the first and fourth years of the study (Table 8).
The results of the year-long study of the abundance of filamentous fungi present in grass rhizosphere showed a different trend than the number of bacteria. Analysis of averaged results indicated that the rhizospheres of perennial rye-grass and common meadow-grass were the richest in filamentous fungi, while the amount of microorganisms significantly increased with the sewage sludge dose. Fungal count in perennial rye-grass significantly increased for the dose of $150 \mathrm{t}^{\circ} \mathrm{ha}^{-1}$ in the two first years of the study, and for the doses of 60 and $150 \mathrm{t}^{\circ \mathrm{ha}^{-1}}$ in 2006, reaching a similar level. Fungal count isolated from common meadow-grass in the first year of the study significantly decreased for the dose of $60 \mathrm{t}^{\circ} \mathrm{ha}^{-1}$ in comparison to the control, and insignificantly increased for the dose of $150 \mathrm{t} \cdot \mathrm{ha}^{-1}$. In the first year of the study, the population size of filamentous fungi in the rhizosphere of red fescue decreased insignificantly for the dose of $60 \mathrm{t} \cdot \mathrm{ha}^{-1}$ and significantly for the dose of $150 \mathrm{t} \cdot \mathrm{ha}^{-1}$. In 2005 and 2006 the fungal count increased with dose, and only in 2005, for the dose of $60 \mathrm{t} \cdot \mathrm{ha}^{-1}$, did it not demonstrate any significance as compared to the control (Table 9).

Diversity in the count of yeast-like fungi was much lower than for filamentous fungi. In terms of grass species, the rhizosphere of perennial rye-grass was the richest in yeast-like fungi, and the lowest count was

Table 10. Count of yeast-like fungi isolated from the rhizosphere of grasses $\left(\log 10 \mathrm{CFU} \cdot \mathrm{g}^{-1} \mathrm{soil}\right)$.

\begin{tabular}{|c|c|c|c|c|c|c|c|c|c|c|c|c|c|}
\hline \multirow{2}{*}{\multicolumn{2}{|c|}{$\begin{array}{c}\text { Strain of grass } \\
\begin{array}{c}\text { Dose of sewage } \\
\text { sludge }\left(\mathbf{t} \cdot \mathbf{h a}^{-1}\right)\end{array}\end{array}$}} & \multicolumn{3}{|c|}{ Perennial rye-grass } & \multicolumn{3}{|c|}{ Common meadow-grass } & \multicolumn{3}{|c|}{ Creeping red fescue } & \multicolumn{3}{|c|}{$\begin{array}{c}\text { Mean dose of sewage } \\
\text { sludge }\end{array}$} \\
\hline & & $\mathbf{0}$ & 60 & 150 & $\mathbf{0}$ & 60 & 150 & $\mathbf{0}$ & 60 & 150 & 0 & 60 & 150 \\
\hline \multirow{3}{*}{ हैं } & $\mathbf{I}$ & $3.85 \mathrm{e}-\mathrm{g}$ & $4.20 \mathrm{~d}$ & $4.34 \mathrm{~cd}$ & $4.56 b$ & $4.46 \mathrm{bc}$ & $3.70 \mathrm{~g}-\mathrm{i}$ & $3.60 \mathrm{hi}$ & $3.70 \mathrm{~g}-\mathrm{i}$ & $3.90 \mathrm{ef}$ & 4.00 & 4.12 & 3.98 \\
\hline & III & $3.60 \mathrm{hi}$ & $3.12 \mathrm{k}$ & $3.37 \mathrm{j}$ & $3.00 \mathrm{k}$ & 3.60hi & $3.80 \mathrm{e}-\mathrm{g}$ & $3.75 f-h$ & $3.56 \mathrm{i}$ & $3.70 \mathrm{~g}-\mathrm{i}$ & 3.45 & 3.43 & 3.62 \\
\hline & IV & $4.18 \mathrm{~d}$ & $4.83 \mathrm{a}$ & $4.74 \mathrm{a}$ & $3.95 \mathrm{e}$ & $4.18 \mathrm{~d}$ & $4.18 \mathrm{~d}$ & $3.60 \mathrm{hi}$ & $4.28 \mathrm{~d}$ & $3.78 \mathrm{e}-\mathrm{g}$ & 3.91 & 4.43 & 4.23 \\
\hline \multirow{2}{*}{\multicolumn{2}{|c|}{ Mean }} & 3.87 & 4.05 & 4.15 & 3.84 & 4.08 & 3.89 & 3.65 & 3.85 & 3.79 & $3.79 \mathrm{Z}$ & $3.99 \mathrm{X}$ & $3.95 \mathrm{Y}$ \\
\hline & & \multicolumn{3}{|c|}{$4.03 \mathrm{~A}$} & \multicolumn{3}{|c|}{ 3.94B } & \multicolumn{3}{|c|}{$3.76 \mathrm{C}$} & & & \\
\hline
\end{tabular}

Results with the same letter (year - dose: small letters; mean for types of grasses: A, B or C; mean for doses: X, Y or Z) are not significantly different; LSD $(\mathrm{p}<0.05)$ 
represented by red fescue. With respect to sludge fertilization, the dose of $60 \mathrm{t}^{\bullet} \mathrm{ha}^{-1}$ stimulated yeast-like cells in the best manner, while a lower value was reached for the dose of $150 \mathrm{t} \cdot \mathrm{ha}^{-1}$, and the lowest value was observed for the control. In 2003 and 2006 we observed a significant increase in fungal count in the rhizosphere of perennial ryegrass as compared to the control, and the differences in the number of cells between the doses were small. The highest value was reached by the control in 2005 , while the dose of $60 \mathrm{t} \cdot \mathrm{ha}^{-1}$ was characterized by the lowest fungal count. In 2003, in the case of common meadow-grass, we found a significant reduction in the value for the dose of $150 \mathrm{t}^{\circ} \mathrm{ha}^{-1}$, while in 2005 we observed a noticeable increase in yeast cell count with a sludge dose. In the last year of the study the fungal count did not change significantly, although the value for both doses was slightly higher as compared to the control. In the rhizosphere of red fescue, similarly to the two above-mentioned grass species, the amount of yeastlike fungi demonstrated a variable tendency depending on the studied year. In the first year of the study, despite the increase in cell count, a significant result was observed only for the dose of $150 \mathrm{t} \bullet \mathrm{ha}^{-1}$. In 2005 the cell count decreased for the dose of $60 \mathrm{t} \bullet \mathrm{ha}^{-1}$ and did not change significantly as compared to the control for the dose of 150 t ha $^{-1}$. In 2006 all the results differed significantly. The highest fungal count was observed for the dose of $60 \mathrm{t} \cdot \mathrm{ha}^{-1}$, and for the highest dose and control it was much lower (Table 10).

Soil bacteria and bacteria living on the surface of plant roots may have antagonistic properties against pathogenic fungi. The group of microorganisms with a high potential for reducing plant diseases includes Pseudomonas spp. bacteria, which has been confirmed by numerous scientific studies [40-41]. Analysis of the microbial count of the grass rhizosphere (Tables 8-9) demonstrates that the Pseudomonas spp. bacteria count increased with the dose of sewage sludge, while the filamentous fungi count did not significantly change. This may indicate that the limiting factor for fungal development was the count of antagonistic bacteria, which increased under the influence of fertilization. As indicated by Garbeva et al. [42], among the investigated populations of Pseudomonas spp., bacteria isolated from the rhizosphere of grasses and corn were characterized by the strongest antagonistic properties against pathogens. The author also points out two important factors, which are soil and plant species that determine the population structure of rhizosphere bacteria of the Pseudomonas and Bacillus genera.

Diazotrophic (non-symbiotic) bacteria, producing nitrogenase, belong to the bacteria responsible for the fixation of molecular nitrogen. The studies of wheat root zone [43] showed that Azotobacter spp. colonizes the rhizosphere $\left(2 \cdot 10^{5} \mathrm{CFU}\right)$ and soil $\left(1.5 \cdot 10^{5} \mathrm{CFU}\right)$ most frequently, while it is less frequent in the direct vicinity of plant roots $\left(6.2 \cdot 10^{4} \mathrm{CFU}\right)$. The amount and activity of these bacteria in the soil are mainly dependent on the type of soil, the type of agrotechnical treatments, and the use of chemicals in agriculture [44-46]. Bacteria of the Azotobacter genus can fix significant amounts of nitrogen in the soil environment (about 5-17 $\mu \mathrm{g} \mathrm{N} \cdot \mathrm{g}^{-1}$ ). As has been shown, this process is more efficient in clayey soil than in sandy soils [44]. The data presented by Mujiyati and Supriyadi [46] prove that fertilization influences the count of nitrogen-fixing bacteria. The population growth for $\mathrm{AzO}$ tobacter spp. and Azospirillum spp., originating from the rhizosphere of a chili pepper plantation, equalled $43 \%$ and $16 \%$ sequentially for mineral fertilization, and $29 \%$ and $68 \%$ for manure. The use of fertilization also increased nitrogen content in the soil by $41 \%$ in the case of mineral fertilizer, and by $36 \%$ in the case of manure. Moreover, the sorption capacity and the amount of organic carbon and organic matter increased. As shown in the studies [47], the count of Azotobacter chroococum varies depending on the isolation site. The author also points out that the important factors determining the occurrence of $A$. chroococum are $\mathrm{pH}$ and the contents of $\mathrm{N}$ and $\mathrm{C}$, as well as of heavy metals and other xenobiotics. Additionally, the studies demonstrated that $A$. chroococum bacteria form communities that vary within a species regardless of the environment from which they were isolated, but their count in downtown lawns and other ecosystems present within the area of Poland differs.

The high microbial activity and normal course of biochemical processes in the soil indicate its good quality and its proper functioning, which has a crucial effect on supplying plants with nutrients by bacteria - especially in soils to which no mineral fertilization is applied. Microbial activity depends on the parameters of the soil environment (e.g., pH value) and tillage system. In quantitative studies of bacteria in the ecological system in soil under winter wheat, the bacterial count of the Azotobacter genus equalled $98 \mathrm{CFU} \cdot \mathrm{g}^{-1}$ on $23 \mathrm{June}$ and $143 \mathrm{CFU} \cdot \mathrm{g}^{-1}$ on 15 September. In the conventional system, no presence of Azotobacter spp. was found [48].

The study on the impact of different grass species and the presence of earthworms (Aporrectodea caliginosa) on the count of bacteria of the Azospirillum genus demonstrated that the bacteria occurred in the soil in a form not connected to the roots - both in red fescue and in the cultivation of a mixture of different grass species - throughout the growing season. There was no correlation between the amounts of isolated bacteria, changes in diversity of varieties in the grass mixture, and the presence of earthworms [49].

Microbiological analysis of the soil under lawns fertilized with nitrogen at five different doses (from 50 to $200 t^{\bullet} \mathrm{ha}^{-1}$ ) indicated that the doses of fertilizer were not a factor that would determine the bacterial and fungal counts in the soil, but weather conditions and the date of collection of samples turned out to be significant. The highest count of bacteria was recorded in May and June, and the highest count of filamentous fungi in August [50]. On the other hand, the application of sewage sludge at its highest dose $\mathrm{N}\left(170 \mathrm{t} \bullet \mathrm{ha}^{-1}\right)$ to Virginia mallow (Sida hermaphrodita (L.) Rusby) resulted in a significant increase in the count of soil fungi and bacteria. It was also found that the period of the most frequent occurrence of bacteria was in July. The count of filamentous fungi contained in the 
soil was strongly linked to weather conditions during the experiment as well [51].

Analysis of fungal communities in the soil under winter wheat cultivation demonstrated that the layer $10-20 \mathrm{~cm}$ below the surface of the earth is dominated by Penicillium spp. (17\%) and Trichoderma harzianum (9\%) taxa in the ecological system, and by Alternaria alternata (11\%), Fusarium culmorum (7\%), and Penicillium spp. $(7 \%)$ taxa in the conventional system. The results indicate a greater share of saprotrophic fungi in the soil cultivated in an ecological system [52].

The use of sewage sludge, especially at a dose of $60 \mathrm{t} \mathrm{ha}^{-1}$, influenced the growth of yeast-like fungi. The presence of yeast cells in the soil environment is responsible for the decomposition of dead organic matter, has a positive impact on the soil macrofauna, and exhibits antagonism against pathogens [53-54].

\section{Conclusions}

The largest community of microorganisms was isolated from the control not fertilized with sewage sludge, and the smallest one after fertilization with a dose of $60 \mathrm{t} \cdot \mathrm{ha}^{-1}$. Despite this, the worst parameters (the highest degree of dominance by one species, the lowest level of diversity among taxa) were obtained for analysis of the rhizoplane population originating from grasses fertilized with sludge at a dose of $150 \mathrm{t} \cdot \mathrm{ha}^{-1}$. Furthermore, in grasses fertilized with the highest dose used in the study, not only a higher occurrence of $F$. oxysporum and other closely related pathogens was observed, as compared to the control, but also a decrease in the share of fungi potentially antagonistic against pathogens was observed. On the other hand, at a dose of $60 \mathrm{t} \bullet \mathrm{ha}^{-1}$, both the share of pathogens and of potentially antagonistic fungi such as Aureobasidium spp., Trichoderma spp., and other saprotrophs was higher as compared to the control.

Perennial rye-grass had the most favourable population indices and the lowest dominance of the root zone by fungi of the Fusarium genus. This species was characterized by a significantly more numerous fungal community. All of the analysed parameters, including a better response of rhizosphere bacteria of the Azotobacter genus and yeast-like fungi to the doses of sludge than in other grass species, indicate that this grass is characterized by a low susceptibility to root zone colonization by pathogens, and a potentially better use of the nutrients present in the soil and provided by sewage sludge.

Due to the small number of reports on the effects of fertilization of sewage sludge on the microorganisms occurring in the root zone of lawn grasses, it is proved that the use of low doses of sewage sludge on $\left(60 \mathrm{t} \cdot \mathrm{ha}^{-1}\right)$ improves the microbiological parameters. There is also evidence that potentially pathogenic fungi less frequently colonize the root zone of perennial ryegrass combined with fertilization with sewage sludge. Therefore, the combination of sewage sludge fertilization with the use of perennial rye-grass is the most optimal variant, contributing to the formation of lawns with low emissions of toxigenic fungi and producing the appropriate communities of microorganisms responsible for the high quality of the grass.

\section{References}

1. KOSOBUCKI P., CHMARZYŃSKI A., BUSZEWSKI B. Sewage Sludge Composting. Pol. J. Environ. Stud. 9 (4), 243, 2000.

2. ANTONIOUS G.F., DENNIS S.O., UNRINE J.M., SNYDER J.C. Heavy Metals Uptake in Plant Part of Sweet potato Grown in Soil Fertilized with Municipal Sewage Sludge. Int. J. Geol. 5 (1), 14, 2011.

3. RULKENS W. Sewage Sludge as a Biomass Resource for the Production of Energy: Overview and Assessment of the Various Options. Energy \& Fuels 22 (1), 9, 2008.

4. ANTONKIEWICZ J. Effect of Sewage Sludge and Furnace Waste on the Content of Selected Elements in the Sward of Legume-Grass Mixture. J. Elem.. 15 (3), 435, 2010.

5. PAJAূK T. Thermal Treatment as Sustainable Sewage Sludge Management. Environ. Prot. Eng. 39 (2), 41, 2013.

6. KEPP U., MACHENBACH I., WEISZ N., SOLHEIM O. E. Enhanced stabilisation of sewage sludge through thermal hydrolysis - three years of experience with full scale plant. Water Sci. Technol. 42 (9), 89, 2000.

7. KALISZ L., SAŁBUD J. Dewatering of Anaerobically Stabilized Sludge on Reed Beds. Ochr. Środ. Zas. Nat. 30, 105, 2007 [In Polish].

8. CHIANG K-Y., HUANG H-J., CHANG C-H. Enhancement of Heavy Metal Stabilisation by Different Amendments During Sewage Sludge Composting Process. J. Environ. Eng. Manage. 17 (4), $249,2007$.

9. GRABOWSKI K., GRZEGORCZYK S., GŁOWACKA-GIL A. The Effect of Sludge on Initial Growth and Development of Lawn Grasses in Background of Different Mix Types and Sowing Times. Pol. J. Environ. Stud. 17 (6), 975, 2008.

10. GONDEK K. Assessment of the Influence of Sewage Sludge Fertilization on Yield and Content of Nitrogen and Sulphur in Maize (Zea mays L.). J. Elem. 15 (1), 65, 2010.

11. BERGKVIST P., JARVIS N., BERGGREN D., CARLGREN K. Long-term effects of sewage sludge applications on soil properties, cadmium availability and distribution in arable soil. Agr. Ecosyst. Environ. 97 (1-3), 167, 2003.

12. GONDEK K., KOPEĆ M. Heavy metal binding by organic substance in sewage sludge of various origin. EJPAU. 9 (3), 1, 2006.

13. HINSINGER P., BENGOUGH A.G., VETTERLEIN D., YOUNG I.M. Rhizosphere: biophysics, biogeochemistry and ecological relevance. Plant Soil. 321 (1-2), 117, 2009

14. BERENDSEN L.B., PIETERSE C.M.J., BAKKER P.A.H.M. The rhizosphere microbiome and plant health. Trends Plant Sci. 17 (8), 478, 2012.

15. AHEMAD M., KIBRET M. Mechanisms and applications of plant growth promoting rhizobacteria: Current perspective. Journal of King Saud University - Science. 26 (1), 1, 2014.

16. PRZEMIENIECKI S.W. KUROWSKI T.P., KORZEKWA K., KARWOWSKAA. The effect of psychrotrophic bacteria isolated from the root zone of winter wheat on selected biotic and abiotic factors. J. Plant. Protect. Res. 54 (4), 407, 2014.

17. WHIPPS J.M. Prospects and limitations for mycorrhizas in biocontrol of root pathogens. Can. J. Bot. 82, 1198, 2004.

18. ROSA M.M., TAUK-TORNISIELO S.M., RAMPAZZO P.E., CECCATO-ANTONINI S.R. Evaluation of the 
biological control by the yeast Torulaspora globosa against Colletotrichum sublineolum in sorghum. World J. Microb. Biot. 26 (8), 1491, 2010

19. BEARD J.B., GREEN R.L. The role of turfgrasses in environmental protection and their benefits to humans. J. Environ. Qual. 23 (3), 452, 1994.

20. HARKOT W., CZARNECKI Z. Intensity of re-growing of Polish cultivars of lawn grass grown on mineral soil with mechanically damaged surface layer. Grassland in Poland. 3, 59, 2000 [In Polish].

21. GARLING D.C., BOEHM M.J. Temporal effects of compost and fertilizer applications on nitrogen fertility of golf course turfgrass. Agron. J. 93, 548, 2001.

22. LOSCHINKOHL C., BOEHM M.J. Composted biosolids incorporation improves turfgrass establishment on disturbed urban soil and reduces leaf rust severity. Hortscience. 36, 790, 2001.

23. WIEWIÓRA B., PROŃCZUK M. Micro-organisms colonizing seeds of grasses and their influence on turf diseases. Biul. IHAR. 214, 269, 2000 [In Polish].

24. BARNETT L. Illustrated genera of imperfect fungi. Burgess Publishing Company. Minneapolis: 1, 1962.

25. ELLIS M. B. Dematiaceous Hyphomyces. Comm. Myol. Inst. Kew, Surrey: 1, 1971.

26. GAMS W. Cephalosporium-artige Schimmelpilze (Hyphomycetes). VEB Gustav Fischer Verlag, Jena: 1, 1971.

27. DOMOSCH K.H., GAMS W. Fungi in agricultural soils. Longman Group Limited, London: 1, 1972.

28. SKIRGIEŁŁO A., ZADARA M., ŁAWRYNOWICZ M. Algal fungi (Phycomycetes), Pin mold fungi (Mucorales), Kłębiankowe (Endogonales), in: Fungi (Mycota). Vol. X. PAN, Warszawa-Kraków: 1, 1979 [In Polish].

29. KWAŚNA M., CHEŁKOWSKI J., ZAJKOWSKI P. Sickle (Fusarium), in Fungi (Mycota). Vol XXII. PAN, WarszawaKraków: 1.1991.

30. Index Fungorum http://www.indexfungorum.org/ (accessed: 14.10.2014).

31. WIERNE J. The life and evolution of the biosphere. Polish Science Publishing: 410, 2012 [In Polish].

32. KUROWSKI T. . BIENIASZEWSKI T., WYSOCKA U. Fungi colonizing field bean (Vicia faba L. minor HARZ.) seeds damaged by broad bean weevil (Bruchus rufimanus BOH.). Zesz. Prob. Post. Nauk Rol. 550, 191, 2010 [In Polish].

33. SURVILIENĖ E. Reaction of micromycetes to antagonistic organisms and fungicides in substrate. Biologija 1, 14, 2002.

34. PROŃCZUK M., PROŃCZUK S. Initial assessment of lawn grass resistance to diseases in Poland. Genet. Pol. 35A, 341, 1994 [In Polsih].

35. PROŃCZUK M. Major disease of lawn grass in Poland. Biul. IHAR, 199, 157, 1996 [In Polish].

36. SMILEY R.W., DERNOEDEN P.H., CLARKE B.B. Compendium of knowledge about grass diseases. 3rd ed., The American Phytopathological Society: St Paul: pp. 17102, 2005.

37. PLĄSOWSKA E., WOLSKI K., MOSZCZYŃSKA E., ZACHARKIEWICZ-WITAN K. Grass healthiness evaluation on football pitches under intensive terf wear. Zesz. Nauk. UP we Wrocławiu. Roln. LXXXVIII. 545, 221, 2006 [In Polish].

38. PAŃKA D., JASKE M., SZCZEPANEK M. Health Status of Perennial Ryegrass (Lolium perene L.) in Relation to Sowing Method and Period of Utilization. Prog. Plant Prot. 50 (2), 949, 2010 [In Polish].

39. JANKOWSKI K., TKACZUK C., JANKOWSKA J.,
CZELUŚCIŃSKI W. Estimation of over wintering and degree of infestation with snow mold of lawn grasses depend on fertilization and hydrogel. Fragm. Agron. 28 (2), 26, 2011 [In Polish].

40. DEORAA., HASHIDOKO Y., ISLAM Md. T., AOYAMA Y., ITO T., TAHARA S. An antagonistic rhizoplane bacterium Pseudomonas sp. strain EC-S101 physiologically stresses a spinach root rot pathogen Aphanomyces cochlioides. J. Gen. Plant. Pathol. 72, 57, 2006.

41. LEÓN M., YARYURA P.M., MONTECCHIA M.S., HERNÁNDEZ A.I., CORREA O.S., PUCHEU N.L., KERBER N.L., GARCÍAA.F. Antifungal activity of selected indigenous Pseudomonas and Bacillus from the soybean rhizosphere. Int. J. Microbiol. 2009, 1, 2009.

42. GARBEVA P., VAN ELSAS J.D., VAN VEEN J.A. Rhizosphere microbial community and its response to plant species and soil history. Plant Soil. 302 (1-2), 19, 2008.

43. AKOND M.A., MUBASSARA S., RAHMAN M.M. Distribution and abundance of Azotobacter in wheat fields of Bangladesh. Banglad. J. Microbiol. 24 (2), 151, 2007.

44. KIZILKAYA R. Nitrogen fixation capacity of Azotobacter spp. strains isolated from soils in different ecosystems and relationship between them and the microbiological properties of soils. J. Environ. Biol. 30 (1), 73, 2009.

45. KRZYŚKO-ŁUPICKA T., GRATA K. Ecological effect of phosphoorganic herbicide on soil diazotrophs in autumn. Part I. Ecol. Chem. Eng S. 15 (1), 95, 2008 [In Polish].

46. MUJIYAT I., SUPRIYAD I. Effect of manure and NPK to increase soil bacterial population of Azotobacter and Azospirillus in chili (Capsicum annum) cultivation. Bioscience 1 (2), 59, 2009.

47. LENART A. Occurence, charakteristics, and genetic diversity of Azotobacter chroococum in various soils of sounthern Poland. Pol. J. Environ. Stud. 21 (2), 415, 2012.

48. MARTYNIUK S., KSIĘŻNIAK A., JOŃCZYK K., KUŚ J. Microbiological characteristic of soil under winter wheat cultivated in ecological and conventional system. J. Res. Appl. Agric. Engng. 52 (3), 113, 2007 [In Polish].

49. ROKOSZ-BURLAGA H., WASZEWSKA M. The influence of grass species diversity and earthworm Aporrectodea caliginosa on the number of Azospirillum spp. in soil. Nauka Przyr. Technol. 4 (6), 105. 2010 [In Polish].

50. NIEWIADOMSKA A., KLEIBER T., KLAMA J., SWĘDRZYŃSKA D. The effect of varied nitrogen fertilization on dynamics of soil microbiological composition and enzymatic activity of dehydrogenases under lawns. Nauka Przyr. Technol. 4 (6), 90, 2010 [In Polish].

51. AUGUSTOWICZ J., PIETKIEWICZ S., KALAJI M. H., RUSSEL S. Microbiological state of soil and efficiency of photosynthetic apparatus of virginia mallow (Sida hermaphrodita (L.) Rusby) fertilized with sludge obtained from wastewater treatment stations. Nauka Przyr. Technol. 4 (6), 99, 2010 [In Polish].

52. FRĄC M., LIPIEŃ J., RUTKOWSKA A., OSZUST K., PÓŁTORAK M. Microbiological properties of soil under winter wheat in the ecological and conventional cropping systems. Acta Agrophysica. 18 (2), 245, 2011 [In Polish].

53. RODRIGUES A., CABLE R.N., MUELLER U.G., BACCI JR. M., PAGNOCCA F.C. Antagonistic interactions between garden yeasts and microfungal garden pathogens of leafcutting ants. Antonie van Leeuwenhoek. 96, 331, 2009.

54. YURKOV A.M., KEMLER M., BEGEROW D. Assessment of yeast diversity in soils under different management regimes. Fungal ecol. 5, 24, 2012. 